\title{
Reproductive Cycle of Anadara tuberculosa (Sowerby, 1833) (Bivalvia: Arcidae) in a Mangrove System of the Chone River Estuary, Ecuador
}

\author{
Rodolfo Patricio Panta-Vélez¹, Alexandra Bermúdez-Medranda1, Pedro Mero', Dwight Arrieche², \\ Vanessa Acosta-Balbás ${ }^{1}$ \\ ${ }^{1}$ Facultad de Ciencias Veterinarias. Escuela de Acuicultura y Pesquería. Universidad Técnica de Manabí. Bahía de Caráquez-Manabí, 131101 Ecuador. \\ ${ }^{2}$ Instituto de Investigaciones en Biomedicina y Ciencias Aplicadas, Universidad de Oriente, Cerro Colorado-Cumaná, 6101. Venezuela.
}

Correspondence Author: Rodolfo Patricio Panta-Vélez, Facultad de Ciencias Veterinarias. Escuela de Acuicultura y Pesquería, Universidad Técnica de Manabí. Bahía de Caráquez-Manabí, 131401 Ecuador.

E-mail: rppanta@gmail.com

Received date: 12 December 2019, Accepted date: 28 January 2020, Online date: 22 February 2020

Copyright: (c) 2020 Rodolfo Patricio Panta-Vélez et al. This is an open-access article distributed under the terms of the Creative Commons Attribution License, which permits unrestricted use, distribution, and reproduction in any medium, provided the original author and source are credited.

\begin{abstract}
The Population structure, sex ratio, sexual maturity index and the gametogenic cycle of Anadara tuberculosa were analyzed between November 2007 and October 2008, in the mangrove estuary of the Chone River. Random samples were collected from the artisanal fishery, for biometric and histologic analysis. Biometric parameters shell length (L), shell height $(\mathrm{H})$, shell thickness $(\mathrm{T})$, total weight $(\mathrm{W})$ and Fulton metabolic index $(\mathrm{K})$ presented significant differences between months and showed an isometric growth model. The metabolic index $(K)$ decreased in inverse relationship with $H$. Monthly shell length frequency histograms show population bell shaped distribution, with maximum values between 40$50 \mathrm{~mm}$ L. Histological analysis showed that the sex ratio in different sizes is two females for each male, showing monthly differences between sizes and sexes. The presence of the females was independent of the sizes. with monthly differences $(\chi 2, P>0.05)$. The gametogenic and reproductive cycle was synchronized between sexes. The gonadic index did not differ between sexes, being a mature population with periodic spawning. Both sexes reproduce several times a year, with a low proportion of the population in atresia. Gamete production is continuous, and the reproductive strategy is opportunistic associated with food availability. Casual hermaphroditism was found. A low proportion of the sample analyzed showed individuals with female and male gonads dispersed in male acinus, this being the first report of casual hermaphroditism in A. tuberculosa. Protandric hermaphroditism may be associated with the imbalance of the female sexual proportion. Fishing takes place in a significant proportion of the population that has not reached sexual maturity. The temporal variation of reproductive activity shows that $A$. tuberculosa does not present a synchronicity of sexual maturity with other areas of the Ecuadorian Pacific, important information to establish resource management strategies by location. The results obtained should be considered with a view to raising management actions at the local level that allow sustainable fishing exploitation.
\end{abstract}

Keywords: Population Structure, Metabolic Index, Casual Hermaphroditism, Sexual Proportion, Reproductive Strategy.

\section{INTRODUCTION}

The mangrove cockle Anadara tuberculosa (Sowerby, 1833), is a tropical and subtropical bivalve species distributed from Baja California (Mexico) to Punta Telégrafo (Piuta, Peru) [1]. This species lives buried in muddy bottoms of the intertidal zone, from mangrove forests, mainly Rhizophora mangle and Rhizophora racemosa [2]. In the Pacific region, some species of the Anadara genus reach densities that support artisanal fisheries, with wide acceptance for consumption in national and international markets, occupying a position of relevance in the volumes of bivalve fishing $[3,4,5,6,7,8,9]$. Basic knowledge of its biology has been reported, representing an important fishery item for its consumption and commercialization [10, 11], population abundance [12], growth [13, 14], fertility [15], population structure [16, 17], gametogenic and reproductive cycle [18], condition index [19], and hatchery techniques [20].

In Ecuador, mangrove cockle fisheries are done in almost all the estuaries of the Mangrove Ecological Reserve of CayapasMataje, Estuary of the Muisne River, Estero El Morro and Jambelí Archipelago [7], having and increased fishing effort the last 
decade, reducing up to $50 \%$ the capture yield $[5,6,8]$. Given the decrease in the extraction volumes of the mangrove cockle, annual records indicate that populations may be subject to over-exploitation. Moreover, it would lead in the short term to ban the fishery until this bivalve population is restored. A. tuberculosa supports coastal communities for their economic value and as a source of protein. Mangrove cockle is a natural resource that should be studied to understand the essential aspects of its biology. In addition, the purpose of this research to evaluate the population structure, condition index, and the gametogenic cycle of mangrove cockles of the estuary fishery of the Chone River in order to provide valuable information for the fishing management of this species.

\section{MATERIALS AND METHODS}

\section{Study zone}

The organisms of A. tuberculosa were obtained monthly from artisanal fisheries carried out at low tide between November 2007 and October 2008, in the mangrove ecosystem consisting mainly of Rhizophora mangle, at Santa Martha $\left(0^{\circ} 36^{\prime} 36.9^{\prime \prime} \mathrm{S}-80^{\circ} 24^{\prime}\right.$ $18.3^{\prime \prime W) ~ n o r t h e a s t ~ o f ~ t h e ~ e s t u a r y ~ o f ~ t h e ~ C h o n e ~ R i v e r, ~ E c u a d o r . ~ T h e ~ i n d i v i d u a l s ~ w e r e ~ t a k e n ~ a t ~ r a n d o m ~ a n d ~ w e r e ~ f i x e d ~ i n ~ s i t u ~ b y ~}$ immersion in formalin (10\%) prepared with seawater, avoiding post-mortem changes.

\section{Biometric parameters}

In the laboratory, the organisms were washed with running tap water to remove the formalin. Shell was cleaned, removed epibionts, mud, and organic debris. Monthly biometric data was recorded; shell length (L), shell height $(\mathrm{H})$, shell thickness $(\mathrm{T})$ $( \pm 0.01 \mathrm{~mm})$, and total mass $(\mathrm{W})( \pm 0.01 \mathrm{~g})$ for population analysis.

\section{Histological technique}

Almost half of the individuals collected were randomly selected for histological analysis. A portion of the soft tissue crosssection was dissected from the gonad and digestive gland; tissues were processed for conventional techniques of light microscopy. Paraffin $5 \mu \mathrm{m}$ thick sections were obtained in a Jung Histocut Leica microtome and stained with Mayer hematoxylin and eosin (HE) [21]. Stained sections were examined in an Olympus® Cx40 optical microscope. Sexual maturity stages were classified following descriptions of Lucero-Rincón et al. [22].

\section{Analysis of data}

Biometric data. Average biometric data was compared between months and sexes using a one-way ANOVA. Population structure was analyzed using shell length (SL) frequency at $5 \mathrm{~mm}$ intervals, between months and sexes. Biometric data were analyzed using multiple correlation analysis.

Allometric relationship. Shell length and weight data were analyzed by an exponential regression model. The allometric relationship was obtained according to the equation: $P t=a L t^{b}$; a is the regression coefficient, $\mathrm{b}$ is the slope. It is considered a condition index for isometric growth $(b=3)$, positive allometric growth $(b>3)$ or negative allometric growth $(b<3)$ [23]; $b$ was considered isometric between 2.5-3.5 [24]. All the correlation coefficients (r) were positive and significant.

\section{Fulton condition index}

The Fulton condition index $(\mathrm{K})$ is based on the relationship between the shell length $(\mathrm{L})$ of the organism and its weight (W), which is an expression of the growth and sexual maturity of the organism [25], according to the equation: $K=100\left(W / L^{3}\right)$.

\section{Histologic analysis}

Stained tissue samples were used to evaluate the sex ratio. The gonad maturity stages were classified for a description of the gametogenic cycle and reproductive strategy. A low proportion of the individuals were hermaphrodite with female and male gonads.

\section{Gametogenic cycle and sexual proportion:}

The gametogenic cycle was examined by transforming the monthly data of the maturation stages in maturity percentage frequencies histograms of each sex. Specimens were obtained with male and female gametes, which were described in this genus as casual hermaphroditism $[18,15]$, and were expressed in relative terms as a percentage of hermaphrodites.

\section{Sexual proportion}

Sexual proportion (SP) was obtained by the ratio between the number of females (F) and males (M), using the following equation: $S P=F / M$.

The percentage of frequency of occurrence of hermaphrodites $(\mathrm{Hm})$, is the percentage of hermaphrodites. $\mathrm{N}_{\mathrm{Hm}}$ is the number of hermaphrodites, $\mathrm{N}$ is the total organisms. Was determined with the following equation: $\mathrm{Hm}=\left(\sum \mathrm{N}_{\mathrm{Hm}} / \mathrm{N}\right)^{*} 100$.

\section{Shell length at first sexual maturity}

The first sexual maturity is the cumulative shell length-frequency, where 50\% of the population has mature gametes [26]. It was obtained at $5 \mathrm{~mm}$ shell length intervals, using the equation: $Y=1 /\left(1+e^{(a+b L t)}\right)$; where $\mathrm{Y}$ is the proportion of mature organisms. The sigmoid curve was plotted versus percent cumulative shell length frequency, and first sexual maturity was set at $50 \%$ shell length. 


\section{Gonad Index (GI)}

Gonad index was estimated assigning an absolute value to each sexual maturity stage; 0 for sexual undifferentiation (I), 1 to active development (II), 2 to maturity (III), 3 to spawning (IV) and 4 to post-spawning (V). To estimate GI, the number of individuals in each stage $(\mathrm{Ni})$ is multiplied by the numerical value assigned to the reproductive stage $(0, \mathrm{I}, \mathrm{II}, \mathrm{III}, \mathrm{IV})$, using the formula:

$G I=\left(\left(0 \times N_{I}+1 \times N_{I I}+2 \times N_{I I I}+3 \times N_{I V}+4 \times N_{V}\right) / N_{t}\right):\left(N_{t}=N_{I}+N_{I I}+N_{I I I}+N_{I V}+N_{V}\right)[27]$.

\section{Statistical analysis}

The average values of the biometric parameters and Fulton index were compared between months using a one-way analysis of variance. Significant statistical differences were verified with a posteriori Scheffe's test. The sexual proportion (SP) was analyzed by a Chi-square test $(\chi 2)$ to verify that the number of females and sexual males maintain a 1:1 ratio. The monthly averages of the biometric data (Lt, Al, Gr, Pt), Fulton index (K), maturity index (IM), regression coefficient (b) and sexual proportion (PS) were analyzed by a correlation test. Statistical analyzes were performed at a $95 \%$ level of significance $(\mathrm{P}<0.05)$ [28]. Data analysis was performed using Excell spreadsheets (Microsoft) and Statistica software (Statsoft, TIBCO Sotware Inc, USA).

\section{RESULTS}

\section{Population structure}

\section{Biometric and Population Parameters}

The average biometric parameters of the shell dimensions $(\mathrm{L}, \mathrm{H}, \mathrm{T})$, total weight $(\mathrm{W})$, and Fulton condition factor $(\mathrm{K})$ presented statistically significant differences between months $(\mathrm{P}<0.05)$. The regression coefficients $(\mathrm{b})$ of the allometry equation showed isometric growth; however, only in June, the regression coefficient was isometric negative; the determination coefficient was significant (Table 1).

Population biometric parameters between sexes showed significant differences between months $(\mathrm{P}<0.05)$ of the shell length, total weight, and Fulton condition factor. The maturity index oscillated between 2.87 and 3.45 in females and 3.26-3.89 in males. Sex ratio; the number of females was more significant than males with a sex ratio, statistically different $1: 1$. In the sample collected, $1.14 \%$ cockles showed gonadic hermaphroditism, with active female and male gonads (Table 2).

\section{Population structure}

Monthly size-frequency histograms of the mangrove cockle were uniform. Size classes $(25-30 \mathrm{~mm})$ were observed in June and October. The population showed maximum values at the size classes $35-40 \mathrm{~mm}$ and $40-45 \mathrm{~mm}$, declining at the higher size classes. Most of the sampling period population showed a bell-shaped distribution (Fig 1).

Cumulative SL size class interval of the sample examined varies between $25-75 \mathrm{~mm}$ shell length (SL), with a maximum between $35-50 \mathrm{~mm}$ SL. Both sexes $50 \%$ of the sample analyzed was reached at $40-45 \mathrm{~mm}$; female $(50.82 \%)$ and male $(62.22 \%)$, and at $50-55 \mathrm{~mm}$ SL $90.12 \%$ and $94.89 \%$ of the females and males respectively were harvested. SL showed an inverse relationship with metabolic index $(\mathrm{K})$, and significant differences between size classes.

Table 1: Biometric parameters of A. tuberculosa. Shell length (L), shell height (H), shell thickness (W), total weight (T), Fulton condition factor $(\mathrm{K})$, allometry equation coefficient (a), slope (b), determination coefficient $\left(\mathrm{r}^{2}\right)$. Superscripts indicate significant differences $(\mathrm{P}<0.05)$. The asterisk indicates; the significant difference of isometry $(\mathrm{b} \neq 3)$; Sample data $(\mathrm{N})$.

\begin{tabular}{|c|c|c|c|c|c|c|c|c|c|}
\hline Months & $\mathbf{N}$ & $\mathbf{L}(\mathbf{m m})$ & $\mathbf{H}(\mathbf{m m})$ & $\mathbf{T}(\mathbf{m m})$ & $\mathbf{W}(\mathbf{g})$ & $\mathbf{K}$ & $\mathbf{a}$ & $\mathbf{b}$ & $\mathbf{r}^{\mathbf{2}}$ \\
\hline Nov/2007 & 47 & $41.23 \pm 5.23^{\mathrm{b}}$ & $30.28 \pm 4.22^{\mathrm{c}}$ & $20.45 \pm 3.48^{\mathrm{b}}$ & $23.16 \pm 9.11^{\mathrm{b}}$ & $0.32 \pm 0.02^{\mathrm{b}}$ & 0.0004 & 2.90 & 0.96 \\
\hline Dec & 90 & $45.74 \pm 8.20^{\mathrm{a}}$ & $33.92 \pm 6.89^{\mathrm{a}, \mathrm{b}}$ & $24.18 \pm 5.57^{\mathrm{a}}$ & $29.71 \pm 14.14^{\mathrm{a}}$ & $0.29 \pm 0.04^{\mathrm{b}}$ & 0.0016 & 2.55 & 0.95 \\
\hline Jan/2008 & 49 & $44.29 \pm 6.75^{\mathrm{a}}$ & $33.24 \pm 5.68^{\mathrm{a}, \mathrm{b}}$ & $22.67 \pm 5.33^{\mathrm{a}}$ & $31.61 \pm 14.63^{\mathrm{a}}$ & $0.34 \pm 0.04^{\mathrm{a}}$ & 0.0006 & 2.87 & 0.94 \\
\hline Feb & 50 & $45.02 \pm 7.15^{\mathrm{a}}$ & $32.50 \pm 5.78^{\mathrm{a}, \mathrm{b}}$ & $22.42 \pm 5.28^{\mathrm{b}}$ & $33.99 \pm 18.50^{\mathrm{a}}$ & $0.31 \pm 0.04^{\mathrm{b}}$ & 0.0003 & 2.98 & 0.90 \\
\hline Mar & 98 & $45.44 \pm 7.97^{\mathrm{a}}$ & $33.96 \pm 5.54^{\mathrm{a}, \mathrm{b}}$ & $23.34 \pm 4.98^{\mathrm{a}}$ & $33.90 \pm 16.50^{\mathrm{a}}$ & $0.34 \pm 0.06^{\mathrm{a}}$ & 0.0011 & 2.68 & 0.92 \\
\hline Apr & 48 & $45.15 \pm 9.97^{\mathrm{a}}$ & $34.06 \pm 7.64^{\mathrm{a}, \mathrm{b}}$ & $23.38 \pm 6.76^{\mathrm{a}}$ & $35.00 \pm 24.01^{\mathrm{a}}$ & $0.33 \pm 0.03^{\mathrm{b}}$ & 0.0005 & 2.89 & 0.98 \\
\hline May & 47 & $44.45 \pm 6.01^{\mathrm{a}}$ & $33.70 \pm 5.89^{\mathrm{a}, \mathrm{b}}$ & $23.04 \pm 5.25^{\mathrm{a}}$ & $30.83 \pm 14.91^{\mathrm{a}}$ & $0.33 \pm 0.03^{\mathrm{b}}$ & 0.0003 & 3.05 & 0.97 \\
\hline Jun & 45 & $43.73 \pm 6.60^{\mathrm{b}}$ & $34.13 \pm 4.01^{\mathrm{a}, \mathrm{b}}$ & $22.09 \pm 3.82^{\mathrm{b}}$ & $29.22 \pm 12.29^{\mathrm{a}}$ & $0.35 \pm 0.10^{\mathrm{a}}$ & 0.0070 & $2.20^{*}$ & 0.84 \\
\hline Jul & 48 & $44.42 \pm 5.60^{\mathrm{a}}$ & $34.96 \pm 4.39^{\mathrm{a}}$ & $23.02 \pm 4.21^{\mathrm{a}}$ & $31.38 \pm 12.09^{\mathrm{a}}$ & $0.34 \pm 0.04^{\mathrm{a}}$ & 0.0004 & 2.97 & 0.93 \\
\hline Aug & 43 & $41.19 \pm 4.63^{\mathrm{b}}$ & $32.72 \pm 3.30^{\mathrm{a}, \mathrm{b}}$ & $20.60 \pm 2.53^{\mathrm{b}}$ & $23,93 \pm 6.98^{\mathrm{b}}$ & $0.34 \pm 0.03^{\mathrm{a}}$ & 0.0019 & 2.53 & 0.91 \\
\hline Sep & 50 & $44.54 \pm 4.48^{\mathrm{a}}$ & $32.36 \pm 3.15^{\mathrm{b}}$ & $22.43 \pm 3.04^{\mathrm{b}}$ & $29.01 \pm 8.98^{\mathrm{b}}$ & $0.32 \pm 0.02^{\mathrm{b}}$ & 0.0003 & 3.02 & 0.95 \\
\hline Oct & 96 & $44.14 \pm 7.30^{\mathrm{a}}$ & $32.54 \pm 5.75^{\mathrm{a}, \mathrm{b}}$ & $23.13 \pm 4.86^{\mathrm{a}}$ & $31.87 \pm 18.42^{\mathrm{a}}$ & $0.35 \pm 0.07^{\mathrm{a}}$ & 0.0006 & 2.86 & 0.89 \\
\hline
\end{tabular}


Table 2: Biometric parameters of female and males individuals of A. tuberculosa. Shell length (L). The total weight (T). Fulton condition factor $(\mathrm{K})$. Maturity index $(\mathrm{MI})$. Sexual proportion $(\chi 2)$. Hermaphrodite $(\mathrm{H})$. Different superscripts indicate differences significations $(\mathrm{P}<0.05)$. Asterisk indicates; the significant difference in sex ratio 1: 1. Sample data $(\mathrm{N})$

\begin{tabular}{|c|c|c|c|c|c|c|c|c|c|c|c|c|}
\hline Mo & $\mathrm{N}$ & $\mathrm{L}$ & $\mathrm{W}$ & $\mathrm{K}$ & MI & $\chi^{2}$ & $\mathrm{~N}$ & $\mathrm{~L}$ & $\mathrm{~W}$ & $\mathrm{~K}$ & MI & $\mathrm{H}$ \\
\hline & & $\mathrm{mm})$ & (g) & & & & & $\mathrm{mm})$ & (g) & & & $(\%)$ \\
\hline & & \multicolumn{4}{|c|}{ Females } & & & \multicolumn{4}{|c|}{ Males } & \\
\hline Jov/2007 & 29 & $48.41 \pm$ & $.94 \pm 7.89^{b}$ & $\mathrm{~b}$ & 3.10 & $2.07 *$ & 14 & $42.50 \pm 5.80$ & $24.53 \pm 10.03^{b}$ & $2^{\mathrm{a}}$ & 3.31 & 4.44 \\
\hline Dec & 33 & $5.02 \pm 8.48^{a}$ & $30.81 \pm 5.24^{\mathrm{a}}$ & $0.30 \pm 0.0$ & 3.37 & $2.86^{*}$ & 13 & $44.27 \pm 7.32^{\mathrm{a}}$ & $25.43 \pm 10.53$ & $0.29 \pm 0.04^{b}$ & 3.26 & \\
\hline Jan/2008 & 33 & $1.27 \pm 2.25^{\mathrm{a}}$ & $31.17 \pm 4.53^{\mathrm{a}}$ & $0.34 \pm 0.03^{\mathrm{a}}$ & 3.30 & $2.62 *$ & 13 & $43.23 \pm 4.39^{b}$ & $31.38 \pm 11.00^{b}$ & $0.35 \pm 0$ & 3.54 & 2.08 \\
\hline Feb & 28 & $5.25 \pm 2.85^{\mathrm{a}}$ & $32.79 \pm 7.10^{\mathrm{a}}$ & $0.31 \pm 0.05^{b}$ & 3.07 & 1.75 & 16 & $42.50 \pm 2.16^{b}$ & $23.75 \pm 3.37^{\mathrm{c}}$ & $0.30 \pm 0.03^{\mathrm{a}}$ & 3.63 & \\
\hline Mar & 47 & $.30 \pm 2.20^{\mathrm{a}}$ & $37.46 \pm 4.64^{\mathrm{a}}$ & $0.34 \pm 0.04^{b}$ & 3.15 & $2.35^{*}$ & 20 & $43.85 \pm 3.42$ & $31.85 \pm 7.35^{b}$ & $0.36 \pm 0.10^{b}$ & 3.40 & 2.90 \\
\hline Apr & 36 & $.47 \pm 3.14^{b}$ & $31.28 \pm 7.33^{b}$ & $0.33 \pm 0.03^{b}$ & 3.23 & $3.60 *$ & 10 & $48.40 \pm 6.49^{\mathrm{a}}$ & $41.85 \pm 17.19^{\mathrm{a}}$ & $0.33 \pm 0.03^{\mathrm{a}}$ & 3.89 & \\
\hline May & 33 & $\pm 2.40^{\mathrm{a}}$ & $32.71 \pm 5.25^{\mathrm{a}}$ & $0.33 \pm 0.02^{b}$ & 3.12 & $4.13 *$ & 8 & $45.00 \pm 5.76^{\mathrm{a}}$ & $2 \pm 12.31$ & $0.30 \pm 0$ & 3.89 & \\
\hline Jun & 29 & $43.10 \pm 2.24^{b}$ & $28.66 \pm 3.91^{b}$ & $0.35 \pm 0.09^{\mathrm{a}}$ & 3.45 & $3.63^{*}$ & 8 & $45.75 \pm 4.66^{\mathrm{a}}$ & $30.94 \pm 8.32^{b, c}$ & $0.31 \pm 0.02^{b}$ & 3.55 & \\
\hline Jul & 31 & $45.55 \pm 2.11^{\mathrm{a}}$ & $33.41 \pm 4.61^{\mathrm{a}}$ & $0.34 \pm 002^{b}$ & 3.13 & $2.82 *$ & 11 & $43.09 \pm 2.40^{\mathrm{a}}$ & $29.18 \pm 6.39^{b, c}$ & $0.36 \pm 0.08^{\mathrm{a}}$ & 3.73 & \\
\hline Aug & 23 & $40.83 \pm 2.19^{b}$ & $23.01 \pm 3.10^{b}$ & $0.33 \pm 0.03^{b}$ & 2.87 & 1.53 & 15 & $41.40 \pm 1.97^{b}$ & $24.64 \pm 3.05^{\mathrm{c}}$ & $0.34 \pm 0.03^{\mathrm{a}}$ & 3.27 & \\
\hline Sep & 31 & $44.71 \pm 1.66^{\mathrm{a}}$ & $29.40 \pm 3.34^{b}$ & $0.32 \pm 0.03^{b}$ & 2.90 & 2.38 & 13 & $44.89 \pm 2.70^{\mathrm{a}}$ & $29.46 \pm 4.83^{c}$ & $0.32 \pm 003^{\mathrm{a}}$ & 3.85 & 2.22 \\
\hline Oct & 41 & $44.13 \pm 2.21^{b}$ & $30.31 \pm 4.82^{a}$ & $0.33 \pm 0.02^{b}$ & 3.05 & 1.28 & 32 & $43.04 \pm 2.83^{\mathrm{a}}$ & $31.58 \pm 8.46^{b}$ & $0.36 \pm 0.11^{\mathrm{a}}$ & 3.81 & 1.0 \\
\hline
\end{tabular}

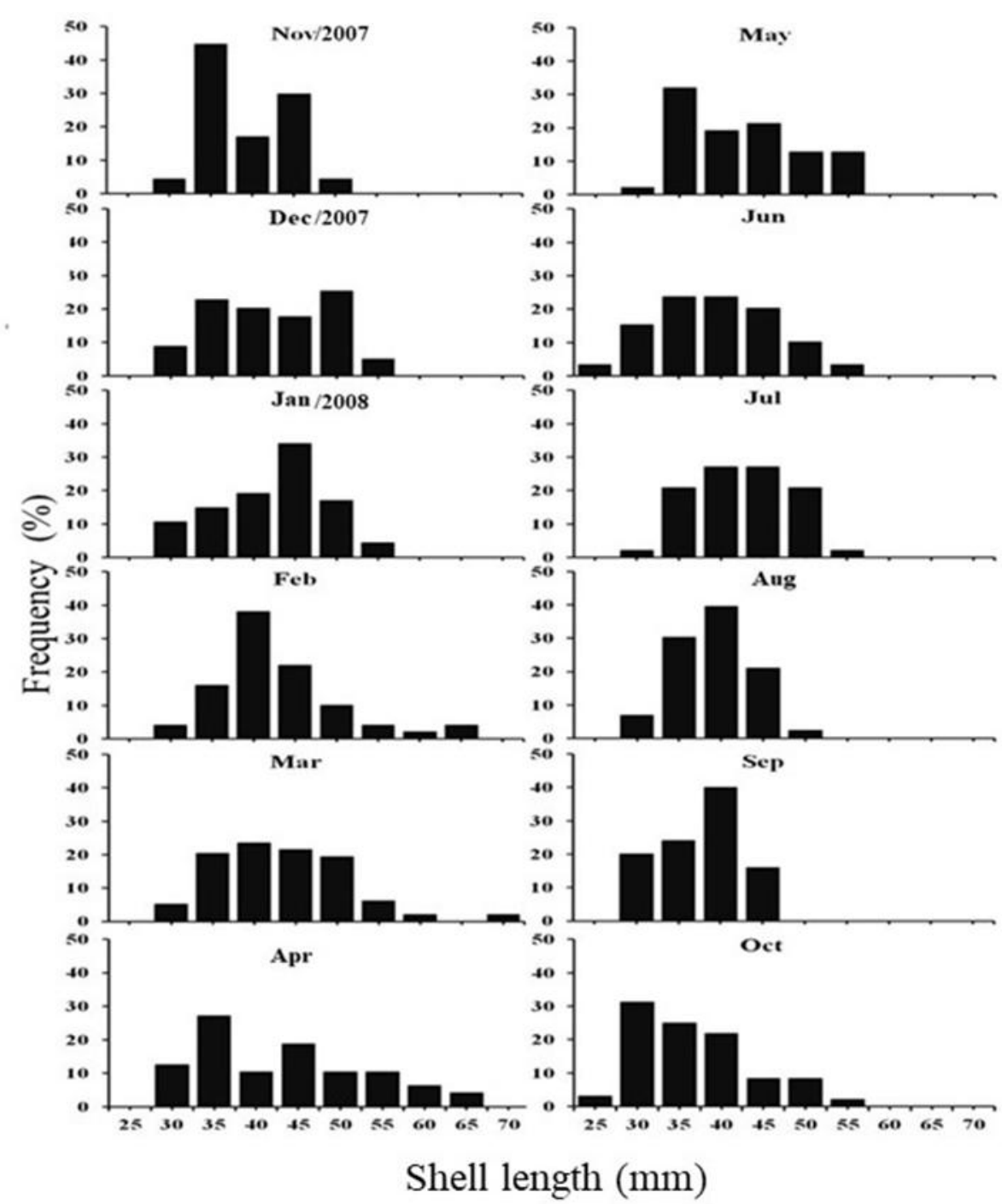

Fig. 1: Population structure of the monthly distribution of the shell length of Anadara tuberculosa in a mangrove system of the Chone river Estuary-Ecuador.

Gametogenic cycle and gonad development stages:

Male gametogenic cycle

Stage II, Development. In the stage of development, acinus is characterized by peripheral spermatogonia arranged in compact rows, followed by developing gametes of smaller size and the reduced nuclear area towards the lumen (Fig 2A). 
Citation: Rodolfo Patricio Panta-Vélez et al., 2020. Reproductive Cycle of Anadara tuberculosa (Sowerby, 1833) (Bivalvia: Arcidae) in a Mangrove System of the Chone River Estuary, Ecuador. Advances in Environmental Biology, 14(2): 1-11. DOI:10.22587/aeb.2020.14.2.1

Stage III, Maturity. In this stage, follicles are totally full of spermatozoa tightly packed. In the periphery, spermatogonia are scarce. Mature acinus is large structures covering a wide area of the gonad, among which the seminiferous tubules can be seen (Fig 2B).

Stage IV, Spawning. During the spawning, the lumen of the acinus, have dispersed spermatozoa. Spawning could be partial or total spawning. Partial spawning presents well-developed acinus with peripheral spermatogonia; however, at the total spawning acinus are empty with some residual gametes (Fig 2C).

Stage V, Post-spawning. Most of the acinus is broken, having residual gametes and cellular debris. As the post-spawning stage progresses, residual tissue and cell debris increases and phagocyte infiltrations occur (Fig 2D).

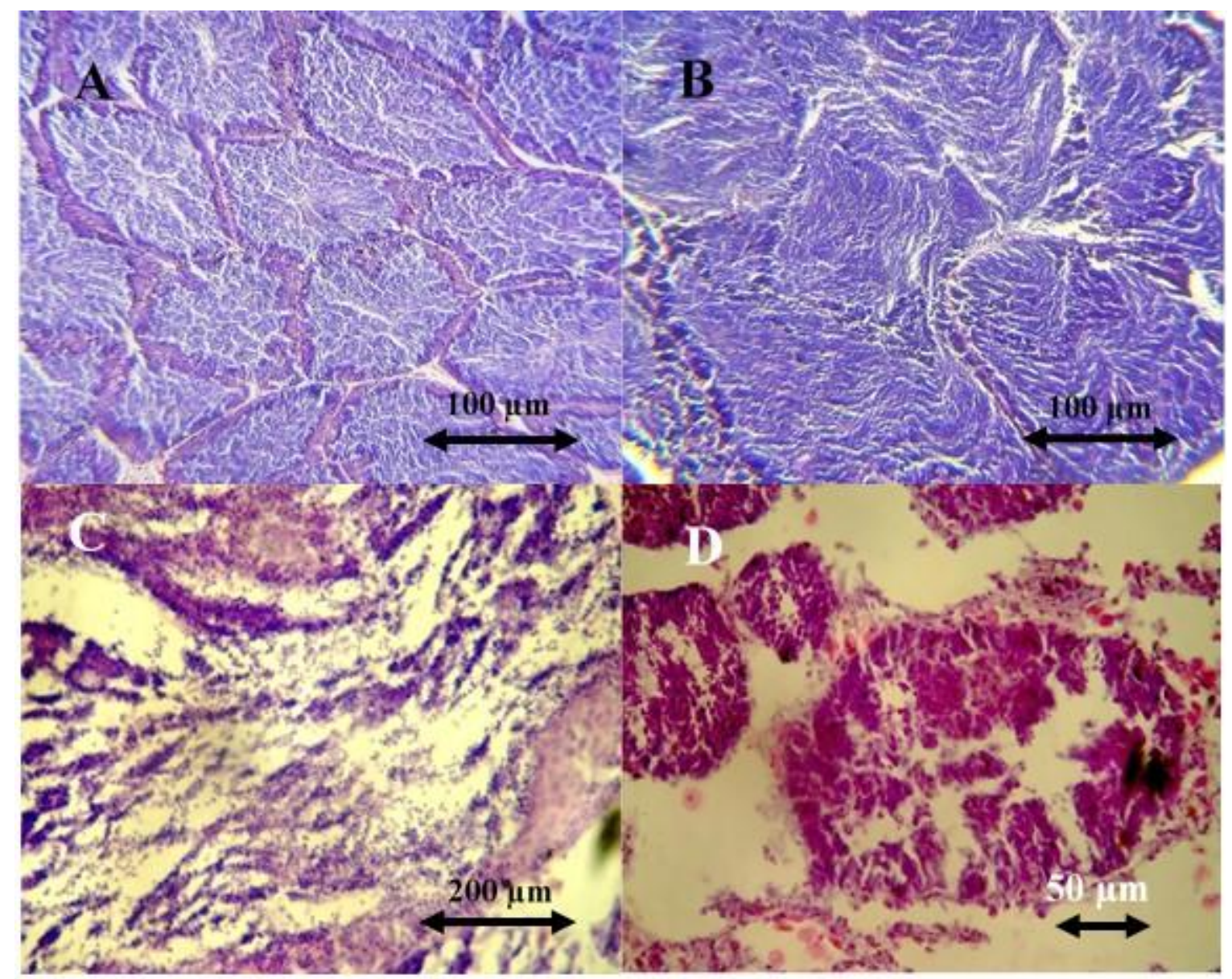

Fig. 2: Sexual maturity stages of males of Anadara tuberculosa. A: Acinus in advanced active gametogenesis, with peripheral spermatogonia, and developing gametes in the lumen. Bar $100 \mu \mathrm{m}$ B: Acinus at maturity stage, with sperm in the lumen. Bar 100 $\mu \mathrm{m} . \mathrm{C}$ : Acinus in a state of spawning; The sperm are scattered in the lumen. Bar $200 \mu \mathrm{m}$ D: Post-spawning stage; Acinus fragments present membrane ruptures. Bar $50 \mu \mathrm{m}$.

\section{Hermaphroditism}

Hermaphrodite individuals presented protandric sex reversal shift, from male to female. Hermaphrodite specimens were scarce all along the sampling period (Table 2). Tissue sections with both sexes gametes were inactive gametogenesis stage; male acinus were small, with rows of spermatogonia and partially dispersed female gametes in the lumen, in which female gametes in different stages of development (ovogonias, pedunculated oocytes) were at the periphery of the acinus, and oocytes at the lumen between undifferentiated male gametes (Figs 3 A, B, C, D). Another sample shown at the same tissue section separated female acinus in the spawning stage and male acinus in active gametogenesis (Fig 3E). 


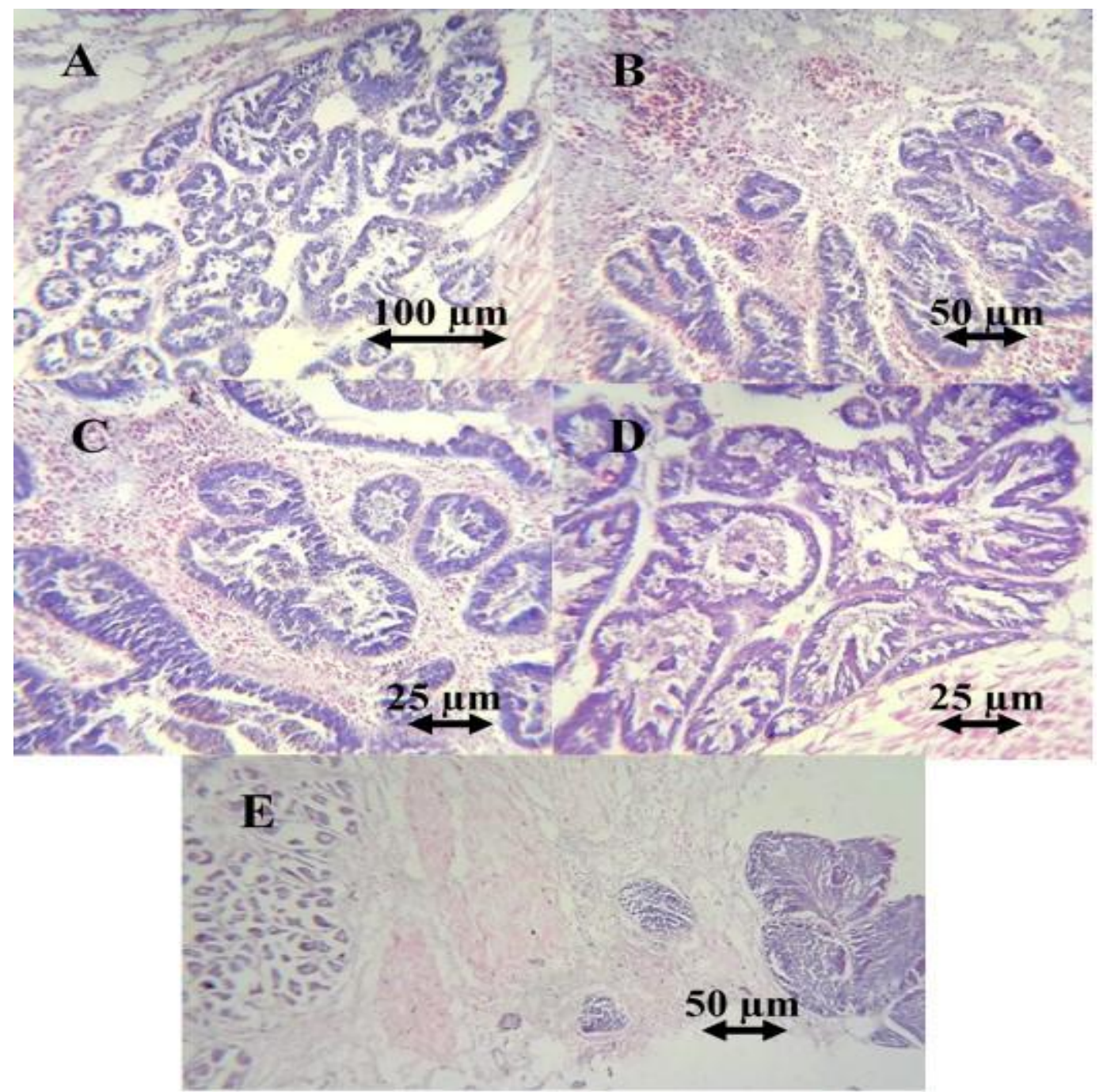

Fig. 3: General characteristics of the hermaphrodite gonads of Anadara tuberculosa. Acini can be seen with the typical cytoarchitecture of males in the stage of active gametogenesis (II) with peripheral spermatogonia and gametes scattered in the lumen, with ovogonies, pedunculated oocytes at the edge of the acini, and scattered oocytes (A: Bar $100 \mu \mathrm{m}, \mathrm{B}$ : Bar $50 \mu \mathrm{m}, \mathrm{C}$ : Bar $25 \mu \mathrm{m}$, D: Bar $25 \mu \mathrm{m})$. In another condition, active female and male acini are seen (E: Bar $50 \mu \mathrm{m})$. The scale bar is indicated.

\section{Female gametogenic cycle}

Stage I, undifferentiated. The undifferentiated stage is a macroscopic feature in which the sex of the organism cannot be identified. Tissue sections show characteristic small acinus, with few gametes in different stages of differentiation, with peripheral oogonia. The acinus is covered with connective tissue (Fig 4A). Stage II, development. The stage of development or gametogenesis is characterized by a higher number of acinus with developing gametes. The acinus is oval, dispersed with oogonia and pedunculated oocytes (Fig 4B). Stage III, Maturity. In the stage of maturity, the acinus is an oval profile and larger than during gametogenesis. Inside the acinus are abundant prominent oocytes, densely packed. Gametes in development phases (ovogonia, pedunculated oocytes) are frequent in a low proportion. The oocytes acquire a polygonal shape when they increase in size and accumulate inside the follicles (Fig 4C). Stage IV, Spawning. In the spawning stage, acinus is partially empty with scarce oocytes in the lumen. Partial spawning show developing gametes and mature oocytes; however, at total, spawning phagocytes are often found with scarce gametes (Fig 4D, E). Stage V, Post-spawning. During the post-spawning stage, acinus is irregular due to rupture of the membranes, with large spaces occupied by cellular debris of the disintegrated oocytes. The residual oocytes exhibit fragmentation of the membranes and disorganization of nuclear material (Fig 4F). 


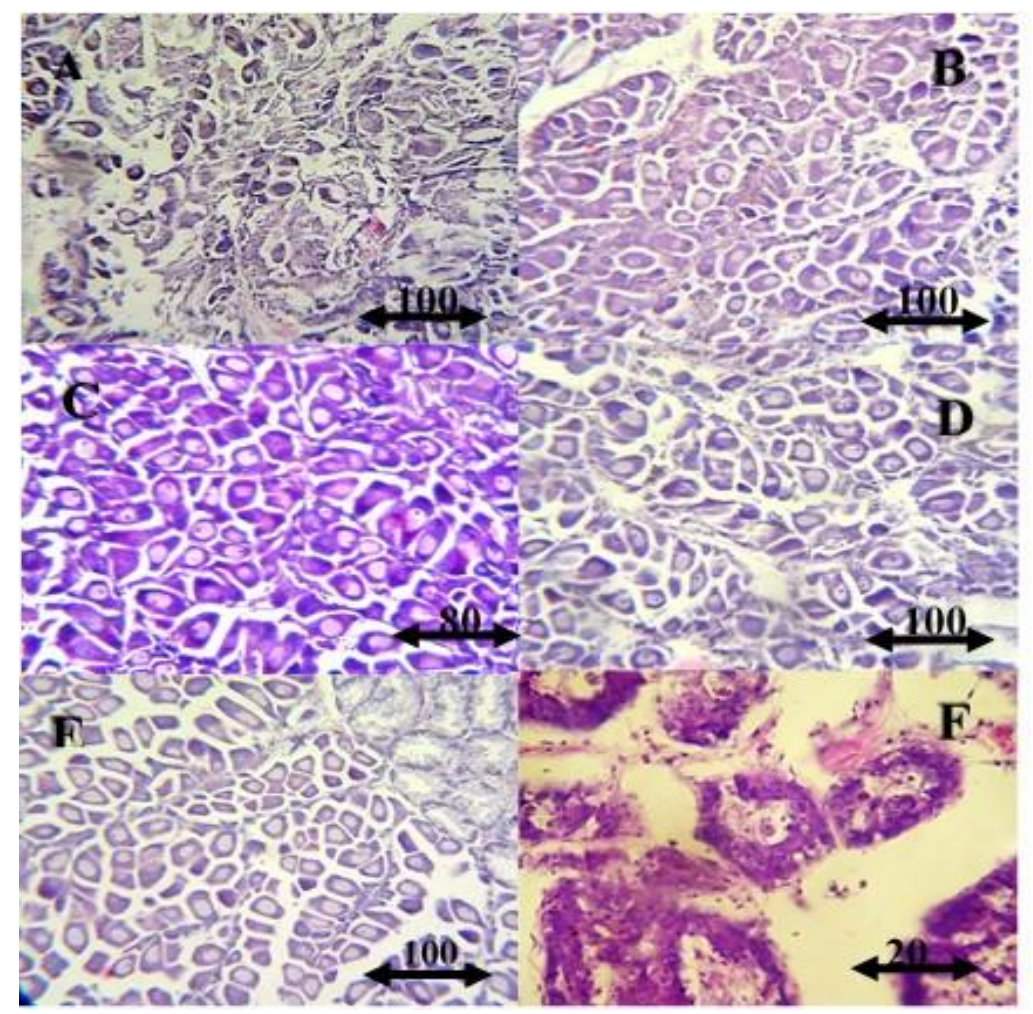

Fig. 4: General features of the gametogenic cycle of females of A. tuberculosa. A: undifferentiated stage. Bar $100 \mu$ m. B: developing stage. Bar $100 \mu \mathrm{m}$. C, maturity stage. Bar $80 \mu \mathrm{m}$. D: Bar $100 \mu \mathrm{m}$ and E: spawning stage. Bar $100 \mu \mathrm{m}$. F: postspawning stage. Bar $20 \mu \mathrm{m}$. OR: residual oocyte

\section{Female reproductive cycle}

Mangrove cockles at the development stage (II) were observed throughout the year, with the maximum in September 2008 and minimum in December 2007. Maturity stage (III) was maximum in November 2007 and minimum in July 2008. Maximum activity of the spawning stage (IV) was observed in December 2007, June and July 2008 and minimum in November 2007. The highest percentage of females in post-spawning (V) was observed in May and minimum in November 2007 (Fig 5A).

\section{Male reproductive cycle}

Throughout the study, developing stage presented a low proportion of organisms (II), with maximum values in June and August. Mature (III) and spawning (IV) stages were constant most of the year, with the maximum in June, and spawning in April, May, September and October. Post spawning stage (V) was maximum in December (Fig 5B).

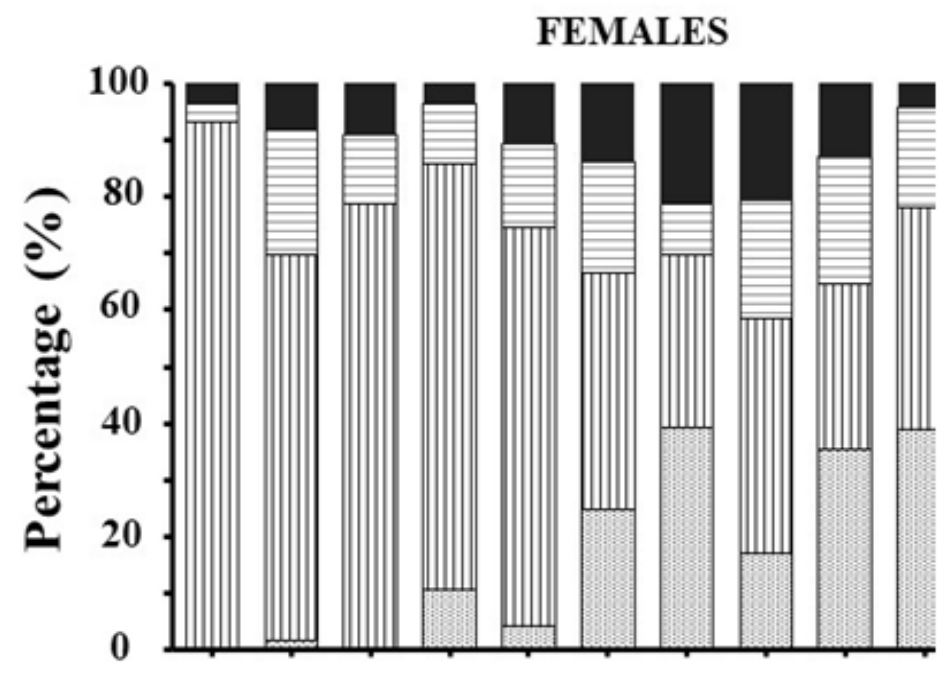




\section{MALES}

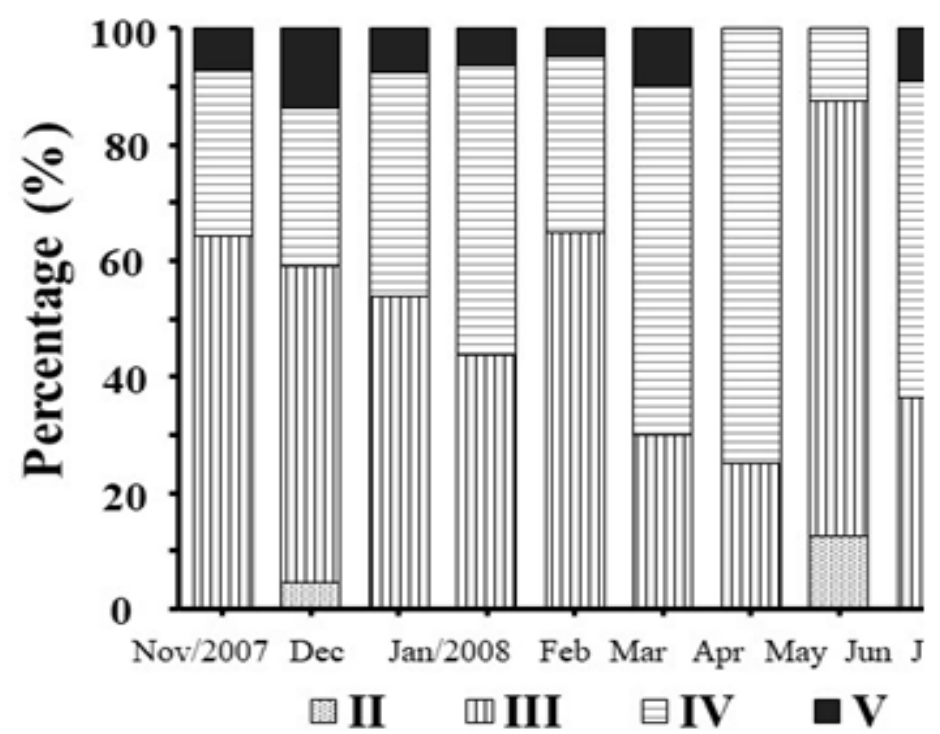

Fig. 5: Annual gametogenic cycle of A. tuberculosa. A.- Females. B.- Males. The percentage frequencies of the sexual maturation stages are indicated

\section{Shell length at first sexual maturity}

Fifty percent of male population was mature at $41.61 \pm 2.61 \mathrm{~mm}\left(\mathrm{r}^{2}=0.99\right)$, and females at $42.98 \pm 2.44 \mathrm{~mm}\left(\mathrm{r}^{2}=0.99\right)($ Fig 6).

\section{A}
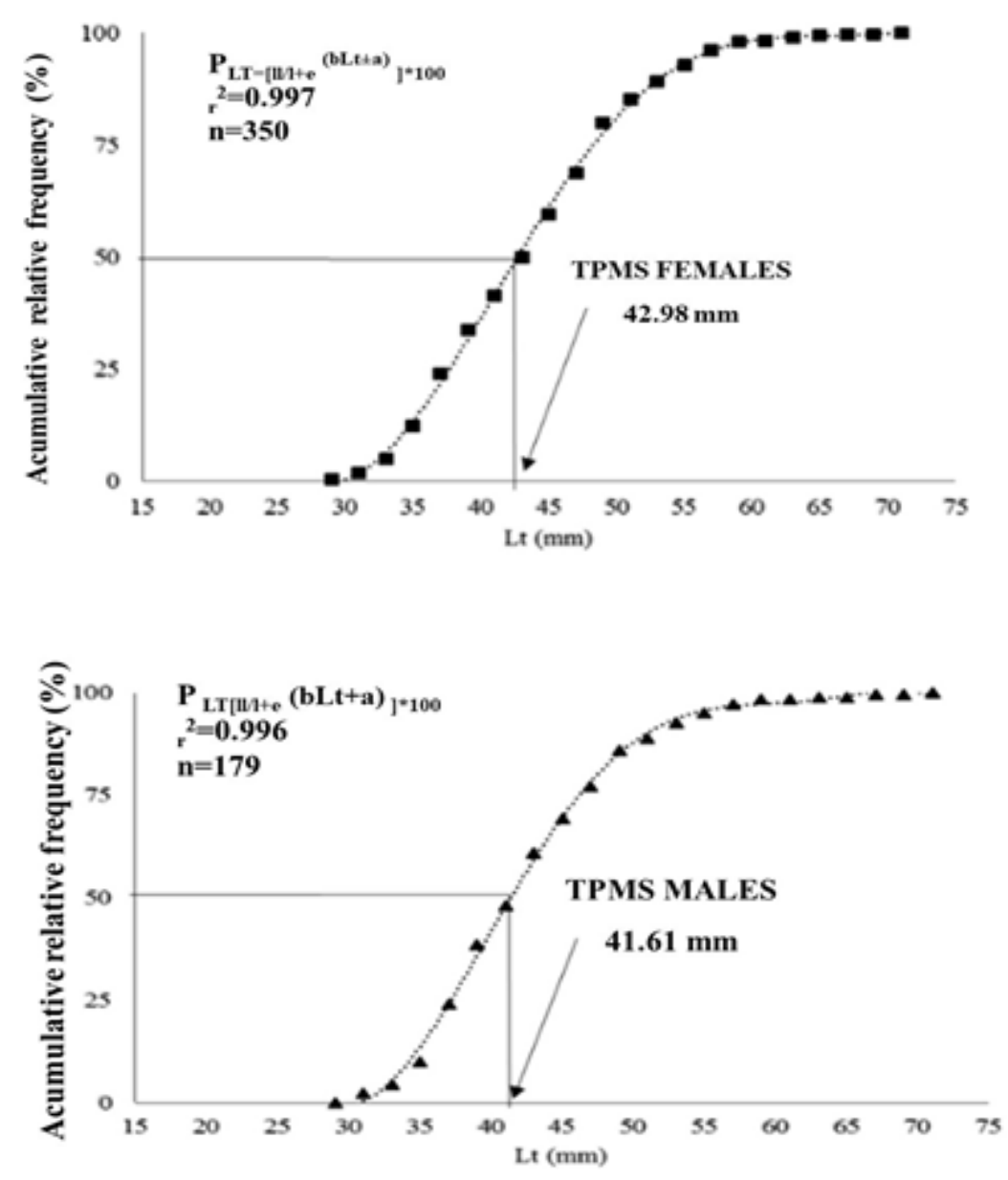

Fig. 6: Size of the first maturity of A. tuberculosa. A - Females. B - Males. 


\section{DISCUSSION}

The genus Anadara is a very valuable bivalve species for consumption on the Pacific coast of America and in some Caribbean countries according to the Food and Agriculture Organization of the United Nations (FAO) [9]. The annual values of the biometric parameters and condition indices (K, b, MI) generally presented two statistically significant different groups, which are alternated every month or two months, without reaching a long period that can be interpreted as a response to a seasonal condition Decreases in the physiological condition could be associated with the availability of food as an energy source of energy accumulation. While the decreases in the indicators of physiological condition $(\mathrm{K}, \mathrm{b})$ can be related to the loss of body mass due to spawning, which is more frequent in males in the estuary of the Chone River.

Population structure of $A$. tuberculosa, fished in the estuary of the river Chone is uniform all along the year, with a considerable proportion of individuals between 30-45 mm, this same fishing pattern, is observed at the Pacific coast from Colombia [3, 5]. However, in Costa Rica, the shell length ranges of 35-45 mm that is captured do not vary significantly [29] because the resource is protected in some areas [12].

The height-frequency histograms of the Chone River, resemble the populations of mangrove cockles harvested from Central and South America. In this study, the samples showed that size-frequency decreased from the interval of 40-45 mm. This finding is generally associated with natural mortality as a consequence of the energy spent in spawning. A. tuberculosa presented two recruitments in June and October, with a length range of size $30-35 \mathrm{~mm}$, with the most significant record in October. In this sense, Cruz and Borda [3], proposed a management strategy to increase biomass and a variable selling price by length to protect individuals under $45 \mathrm{~mm}$ SL. The size at the first sexual maturity and the average maturity size of this species were below the SL allowed in Colombia [14]. These data are important to know in the studies of fisheries of A. tuberculosa, for better management of the resources and the protection of the reserves, since in the estuary of the river Chone, individuals of at least 15 months of age are caught, with gonads mature and a high condition index $(\mathrm{k}, \mathrm{b})$. Flores and Licandeo [16], reported that the fisheries for $A$. tuberculosa in Ecuador had not reached commercial size and recruitment occurs throughout the year. The release of $A$. tuberculosa gametes in the Chone River constantly contributed to spat recruitment and population structure, mainly associated with the rainy season, as occurs in the Colombian Pacific [22]. Most cockle fisheries in Ecuador occurs in estuarine areas associated with mangroves, where catches are significantly dominated by juvenile organisms or individuals below the minimum shell length $[5,6,7]$.

The availability of food could be a limiting factor for the development of the population, in the estuary of the Chone River, due to changes in daily tides, which create periods of anoxia with low food availability in the middle, which can slow down the metabolism and growth of bivalves, during those periods, particularly at low tides. Therefore, the physiological condition of $A$. tuberculosa could be associated with food availability, metabolic rate and energy accumulation. Although the minimum values in the physiological condition $(\mathrm{K}, \mathrm{b})$, obtained in this study, can also be associated with the loss of body mass due to spawning events. In this sense, the environmental conditions of the Ecuadorian sea coast have a characteristic station with high levels of nutrients from the Humboldt current that generates high primary productivity, which generates the main source of food for the filter organisms. A fact that corroborates the above is that in the estuary of the Chone River, values of $18 \mu \mathrm{g} / \mathrm{L}$ of chlorophyll have been reported [30]. The above, argues that the reproductive development and spawning of A. tuberculosa in the studied area is associated with the availability of food, with two reproductive periods, behaviour that coincides with that reported in the Venezuelan Caribbean [31].

The gametogenic cycle of $A$. tuberculosa is continuous and synchronized between the sexes in the estuary of the Chone River, with a characteristic sexual cycle of tropical bivalves. In its life cycle, it presents a development of gonads at an early age, with a predominance of mature gonads most of the year. This study shows that the reproductive behaviour of males differs from females. Reproductive individuals in both sexes were observed for most of the sampling period; this behaviour could be associated with the high reproductive effort found.

Tide oscillations could be associated with periods of spawning and the survival of $A$. tuberculosa in the estuary of the Chone River. Tides could trigger the spawning in the season of high primary productivity. These results are valuable for assessing the measurement of sex pheromones in this species. The regression stage was observed in a low proportion of the population; probably, because some acinus begins to activate producing spermatogonia or ovogonia that matures and degenerates. A new gametogenic cycle begins, which is favoured by high productivity and is associated with continuous reproduction and recruitment throughout the year.

The production of gametes, the maturation of sex cells, in organisms at different stages of gonadal development throughout the annual cycle, is characteristic of tropical bivalve species with continuous reproduction, as reported for Anadara in Mexico [18], Costa Rica [19], Colombia [17] and Venezuela [32]. This reproductive pattern is described as opportunistic; that is, spawning is associated with periods of high food availability [33]. In this species, after spawning, the gonads have the ability to restart the gametogenic cycle, incorporating nutrients for growth and gamete production. However, the reproductive behaviour of the mangrove cockle of the Chone River estuary differs from those reported in southern and northern Ecuador [5, 6, 13, 8], who report that reproductive activity is related to the dry season, and occurs twice a year in August-November. The decrease in salinity is proposed as the modulating factor of reproductive activity, which stimulates the release of gametes [20].

The reproductive behaviour of $A$. tuberculosa in the estuary of the Chone River presented a synchronized pattern of maturation and spawning. The Arcidae family is gonocoric; there is no sexual dimorphism and sex can only be observed in sections of fresh tissue or through histological sections, whose methodology is the most accurate to know this reproductive state of an organism. 
In this sense, this is the first study carried out in Ecuador, which describes the reproductive cycle of $A$. tuberculosa, through histological sections. Hermaphroditic individuals were identified in a low proportion of the sample, and the biometric data could not be associated with the reversal of the protagonist sex. Despite having reported hermaphroditism in some species of the genus Anadara: A. antiquata and A. granosa had a frequency of 1\% [34] and A. tuberculosa in the Colombian Pacific [22]. The higher proportion of females suggests that sexual reversal may occur. This study is the first report of hermaphroditism of $A$. tuberculosa in Ecuador.

Males had a continuous development of gametes and hermaphroditism was associated with a sexual inversion of males to females, with the development of female gametes in male acinus. Sexual reversal probably occurs after male spawning, when the acinus begins a new gametogenic cycle. Although the simultaneous presence of both sexes, also could contribute to generate a greater imbalance of the sexual proportion. Both cases could affect the structure of the population and favour a greater proportion of female sexes. The 1: 1 sex ratio in this species has been reported in Costa Rica [12], Ecuador and Colombia [16, 14].

The cumulative frequency of shell length (SL) shows that more than $50 \%$ of the harvested population did not reach sexual maturity. In addition, these individuals are below SL allowed, which could be reducing landings, population density, which is why this species needs a regulated extraction of mangroves where it is extracted in the Chone River estuary. Artisanal fishing is the only method available, being necessary to evaluate each fishing area and establish specific rules for resource management.

\section{CONCLUSIONS}

The mangrove cockle population of the Chone river has great potential for artisanal harvesting. However, this activity must be protected, avoiding the capture of small individuals. Condition indices, population structure and gametogenic cycle showed an oscillating pattern with maximum values during high primary productivity. The imbalance of the sexual proportion could be associated with the hermaphroditism. Fishing must take place in the population that has reached sexual maturity, and they are allowed the size for commercialization, without jeopardizing the resource of A. tuberculosa.

\section{CONFLICT OF INTEREST}

Authors declare no conflict of interest.

\section{REFERENCES}

[1] Alamo, V. and V. Valdivieso, 1997. Lista sistemática de moluscos marinos del Perú. Segunda Edición, revisada y actualizada. Bol. Inst. Mar Perú, 1-183.

[2] Squires, HG., M. Estévez, M., Barona and O. Mora, 1975. Mangrove cockles, Anadara spp. (Mollusca: Bivalvia) of the Pacific coast of Colombia. Veliger, 18(1): 57-68.

[3] Cruz, R. and C. Borda, 2004, Estado de explotación y pronóstico de la pesquería de la piangua Anadara tuberculosa (Sowerby, 1833) en el Pacífico colombiano. Bol. Invest. Mar. Cost., 24: 221-230.

[4] Borda, C. and R. Cruz, 2004, Reproducción y reclutamiento de molusco Anadara tuberculosa (Sowerby, 1833) en el Pacífico Colombiano. Bol. Invest. Mar. Cost., 25(3): 185-195.

[5] Mora, E. and J. Moreno, 2009, La pesquería artesanal del recurso concha (Anadara tuberculosa y A. similis) en la costa ecuatoriana durante el 2004. Bol. Cient. Técn., 20 (1): 1-16.

[6] Mora, E., J. Moreno, V. Jurado and L. Flores, 2010. La pesquería de la concha prieta (Anadara tuberculosa y Anadara similis) en el 2009: indicadores pesqueros y condición reproductiva en la zona norte y sur de Ecuador. Bol. Cient. Técn., 20(8): 35-49.

[7] Mora, E., J. Moreno, L. Flores and G. Gilbert, 2012. La pesquería del recurso concha Anadara tuberculosa y Anadara similis en los principales puertos de desembarque de Ecuador en el 2011. Bol. Cien. Técn., 22(3): 1-16.

[8] Mendoza, J., 2015. Evaluación de la pesquería de la concha prieta (Anadara tuberculosa) y de la concha mica (Anadara similis) en la Provincia de El Oro. Ecuador. Análisis y Evaluación de Recursos Pesqueros. Informe técnico. Universidad Técnica de Machala. 113pp.

[9] FAO, 2018. El estado mundial de la pesca y la acuicultura 2018. Cumplir los objetivos de desarrollo sostenible. Roma. Licencia: CC BY-NC-SA 3.0 IGO.

[10] Borda, C. and C. Cruz, 2004. Pesca artesanal de bivalvos (Anadara tuberculosa y A. similis) y su relación con eventos ambientales. Pacífico Colombiano. Rev. Invest. Mar., 25(3):197-208,

[11] Jordán, L. and J. Gómez, 2006. Evaluación biológica de Anadara tuberculosa, Golfo de Montijo, República de Panamá. Tecnociencia, 8 (2): 191-205.

[12] Silva-Benavides, A. and R. Bonilla, 2015. Abundancia morfometría de Anadara tuberculosa y A. similis (Mollusca; Bivalvia) en el manglar de Purruja, Golfo Dulce, Costa Rica. Rev. Biol. Trop., 49 (2): 315-320.

[13]Flores, L., 2011. Growth estimation of mangrove cockle Anadara tuberculosa (Mollusca: Bivalvia): application and evaluation of length-based methods. Rev. Biol. Trop., 59: 159-170.

[14]Lucero, C., J. Cantera, D. Gil, O. Muñoz, L. Zapata, N. Cortes, W. Gualteros and A. Manjarrés, 2013. Análisis espacio temporal de la biología reproductiva y el reclutamiento del molusco bivalvo Anadara tuberculosa en la costa del Pacífico Colombiano. Rev. Biol. Mar. Oceanogr., 48(2): 321-334. 
[15] Mzighani, S., 2005. Fecundity and population structure of cockle Anadara antiquata L. 1758 (Bivalvia: Arcidae) from a sandy/muddy beach near Dar es Salaam, Tanzania. WIOJMS, 3: 221-225.

[16] Flores, L. and R. Lincadeo, 2010. Size composition and sex ratio of Anadara tuberculosa and Anadara similis in a mangrove reserve from the northwest of Ecuador. Rev. Biol. Trop., 45: 541-546.

[17] Manjarrés, A., C. Lucero, W. Gualteros, J. Cantera and D. Gil, 2013. Abundancia y madurez sexual de Anadara similis en el manglar de Luisico. Bahía Málaga, Pacífico Colombiano. Bol. Invest. Mar. Cost., 42(2): 215-231.

[18] Pérez-Medina, R., 2005. Biología reproductiva de Anadara tuberculosa (Bivalvia: Arcidae) en el Estero de Santo Domingo, B.C.S., México. CICIMAR, Instituto Politécnico Nacional, La Paz, $71 \quad$ pp. http://www.repositoriodigital.ipn.mx/handle/123456789/14383.

[19] Cruz, R., 1982. Variación mensual del índice de condición del molusco Anadara tuberculosa (Pelecypoda: Arcidae) en Punta Morales. Puntarenas Costa Rica. Rev. Biol. Trop., 30: 1-4.

[20] Retamales, R., R. Panta-Vélez and J. Vélez, 2014. Inducción al desove de la concha prieta Anadara tuberculosa (Sowerby, 1833) en condiciones de laboratorio. La Técnica, 12: 56-63.

[21] Prophet, E., Mills, J. Arrington and L. Sobin, 1992. Métodos histotecnológicos. Instituto de Patología de las Fuerzas Armadas de los Estados Unidos de América. Versión en Castellano por C. Heffes y F, Mullick. 290 pp

[22] Lucero-Rincón, C., Cantera, K., Jaime, R., Gil-Agudelo, D., Muñoz, L., Zapata, O., Cortes, L., Gualteros, N., William, O. and A. Manjarres, 2013. Análisis espacio temporal de la biología reproductiva y el reclutamiento del molusco bivalvo Anadara tuberculosa en la costa del Pacífico colombiano. RBMO, 48(2), 321-334.https://dx.doi.org/10.4067/S071819572013000200011.

[23] Wilburg, K. and G. Owen, 1964. Growth. En Wilburg K.M., Yonge C. M. (Eds.) Physiology of Mollusca. Academic Press. Vol. 1: 211-242.

[24] Froese, R., 2006. Cube law, condition factor and weight-length relationships: history, meta-analysis and recommendations. J. Appl. Ichthyol., 22: 241-253.

[25] Ricker, W., 1975. Computation and interpretation of biological statistics of fish populations. J Fish Res Board Can., 191: 382 pp.

[26] Somerton, D.A., 1980. A computer technique for estimating the size of sexual maturity in crabs. Can. J. Fish. Aquat. Sci., 37: 1488-1494.

[27] Serna-Gallo, I., J. Ruíz-Velasco, H., Acosta-Salmón, E., Peña-Messina, G., Torres-Zepeda and P.E. Saucedo, 2014. Growth and reproduction patterns of the winged pearl oyster, Pteria sterna cultivated in tropical environments of Mexico: Cienc. Mar., 40: 75-88

[28]Zar J., 61999. Biostatistical analysis. Prentice Hall. Englewood Cliffs. 716 pp.

[29] Campos, J., M. Fournier and R. Soto, 1990. Estimación de la población de Anadara tuberculosa (Bivalvia: Arcidae) en Sierpe-Térraba, Costa Rica. Rev. Biol. Trop., 38(2B): 477-480.

[30] Treviño, L., J. Vélez-Falcones and C. Lodeiros, 2019. Effects of stocking density in the grow-out culture of winged pearl oyster Pteria sterna (Gould, 1851). Aquac. Res., 50(3): 964-967.

[31] García-Domínguez, F., A. Haro-Hernández, A. García-Cuéllar, M. Villalejo-Fuerte and S. Rodríguez-Astudillo, 2008. Ciclo reproductivo de Anadara tuberculosa (Sowerby, 1833) (Arcidae) en Bahía Magdalena, México. RBMO, 43(1): $143-152$.

[32] Freites, L., L. Montero, D. Arrieche, J.M. Babarro, P. Saucedo, C. Córdova and N. García, 2010. Influence of environmental factors on the reproductive cycle of the eared ark Anadara notabilis (Röding. 1798) In Northeastern Venezuela. J. Shellfish Res., 29: 69-75.

[33] Freites, L., C. Lodeiros, D. Arrieche and A. Dale, 2014. Reproductive tactics of marine shellfish species from northeastern Venezuela. Editor. Erick Baqueiro Cárdenas, "Spawning, Biology Sexual Strategies and Ecological Effects". Nova Science Publichers, Inc. pp 73-105.

[34] Afiati, N., 2007. Hermaphroditism in Anadara granosa (L.) and Anadara antiquata (L.) (Bivalvia: Arcidae) from central Java. J. Coast. Dev., 10: 171-179. 